\title{
CHARACTERISTICS OF INDICATORS OF HOLTER ECG MONITORING, INDICATORS OF HEART RATE VARIABILITY AND THEIR RELATIONSHIP WITH THE DURATION OF QT INTERVAL IN PATIENTS WITH ACUTE CORONARY SYNDROME
}

Bilous Z. O.

\section{INTRODUCTION}

The most common cardiovascular disease with numerous complications in Ukraine and around the world, despite some significant progress in the study of pathogenesis, clinics, diagnostics and treatment remains the coronary heart disease, which is unfortunately 2-3 times higherin Ukraine than in Europe. The most lethal option for coronary heart disease is myocardial infarction, however, in the first hours of the disease it is not always possible to diagnose and to predict a scenario of subsequent events, so the concept of acute coronary syndrome was formulated as a group of symptoms and signs that allow suspecting acute myocardial infarction or ustable angina ${ }^{1}$. There is an acute coronary syndrome with persistent ST segment elevation on the ECG and without it. The first, in most cases, is transformed into acute MI with a Q wave on the ECG, the second in a sharp MI without a $\mathrm{Q}$ wave or unstable angina. ACS without ST segment elevation is observed more often than with ST segment elevation andthe annual incidence is approximately 3 cases per 1000 inhabitants $^{2}$. The risk of death in patients with MI with ST-segment elevation is higher than in patients without ST elevation, however, after 6 months, the probability of death from cardiovascular causes is aligned in both categories of patients and is 12,0 and $13,0 \%$ respectively ${ }^{3}$.

During recording a normal ECG, the rhythm disturbance in patients is not always possible to record and during the Holter monitoring of the ECG it is possible to estimate the daily number of events to reveal their relationship

${ }^{1}$ Achar S. A., Kundu S., Norcross W. A. Diagnosis of acute coronary syndrome. American Family Physician. 2005. № 72(1). C. 125.

2 Соколов М.Ю., Талаєва Т.В., Ліщишина О.М., Амосова К.М, Божко Л.І., Ємець I.M. та ін. Гострий коронарний синдром без елевації сегмента ST адаптована клінічна настанова, заснована на доказах. 2016. С. 8.

${ }^{3}$ Fox K. A., Eagle K., Gore J. M., Steg P. G., Anderson F. A. The Global Registry of Acute Coronary Events, 1999 to 2009-GRACE. Heart 2010. № 96. C. 1098. DOI 10.1136/hrt.2009.190827. 
with the periods of the day and the occurrence in certain situations, to compare the magnitudes with their reference values and similar indicators of different age groups and nosologies ${ }^{4,5}$.

In ischemic myocardium and during scar formation, myocardial remodeling occurs, myocardial refractory and conduction processes change, myocardial repolarization processes are disrupted, leading primarily to an increase in ventricular fibrillation threshold and is associated with this group of patients with an increased risk of sudden cardiac death ${ }^{6,7}$.

Cardiac arrhythmias occurring in the first 24-72 hours of ACS are of predominantly re-entry type and are classified as early. According to retrospective studies, their impact on prognosis, especially as a risk factor for ventricular rhythm disorders, is negligible. In contrast, late cardiac arrhythmias, i.e. in 3-4 weeks of myocardial infarction, occur at the expense of ectopic foci and increased automatism in the scar area and increase the risk of cardiac death in the long term ${ }^{8,9}$. However, taking into consideration that the most common cause of sudden cardiac death is acute coronary syndrome (in $25 \%$ of patients with coronary heart disease who died suddenly, sudden cardiac death is the first and the only manifestation of the disease), the evaluation of ECG indicators in the first day of ACS may be of importance.

The autonomic nervous system (ANS) is the most important regulator of cardiovascular homeostasis. In patients with impaired coronary blood flow,

4 Жарінов О.Й., Сороківський М.С., Черняга-Ройко У.П. Холтерівське моніторування електрокардіограми: еволюція клінічного застосування, діагностичні можливості, показання. Укр. кардіол. журнал. 2004. № 1. С. 127.

${ }^{5}$ Світлик Г.В. Аритмії у пацієнтів 3 гострим інфарктом міокарда 3 елевацією сегмента ST. Ліки України. 2012. № 9(165). С. 40-41.

6 Пархоменко О.М., Кожухов С.M., Іркін О.І., Лутай Я.М. Гостра лівошлуночкова недостатність у хворих на гострий інфаркт міокарда: взаємозв'язок клінічного перебігу та прогнозу з тривалістю синдрому. Раи. фармакотерапия. 2009. № 3(12). C. 53.

${ }^{7}$ Пархоменко О.М., Гур'єва О.С., Кожухов С.М., Лутай Я.М., Іркін О.І. Перебіг захворювання у хворих із гострим коронарним синдромом із елевацією сегмента ST та збереженою фракцією викиду лівого шлуночка. Укр. мед. часопис. 2012. № 3(89). C. 121 .

${ }^{8}$ Пархоменко О.М., Гур'єва О.С., Кожухов С.М., Лутай Я.М., Іркін О.І. Перебіг захворювання у хворих із гострим коронарним синдромом із елевацією сегмента ST та збереженою фракцією викиду лівого шлуночка. Укр. мед. часопис. 2012. № 3(89). C. 119 .

${ }^{9}$ Zipes D. P., Camm A. J., Borggefe M., Buxton A. E., Chaitman B., Fromer M. et al. Guidelines for the Management of Patients With Ventricular Arrhythmias and the Prevention of Sudden Cardiac Death: Executive Summery. Circulation. 2006. № 114. C. 1112-1118. URL: https://doi.org/10.1016/j.jacc.2006.07.010. 
when the sensitivity of the receptors to the main biological substrates changes against the background of endothelial dysfunction, the likelihood of a distorted effect of ANS on the myocardium and blood vessels increases.

The status of ANS in patients with ACS is reflected in the assessment of heart rate variability (HRV) for at least a 24-hour period.

In recent years, publications have appeared proving the connection between HRV indicators and the course of acute myocardial infarction, such patients have decreased overall variability and humoral influences (VLFs) are more prevalent in spectral assessments in $60,0 \%$ of cases 2 . However, these publications are mainly related to the diagnosis at the stage of scar formation and much less attention is paid to the state of the autonomic nervous system at the stage of acute coronary syndrome, the information about which could possibly help to prevent the early cardiovascular catastrophes $^{10,11}$.

Objective: to characterize the indicators of Holter ECG monitoring, heart rate variability and to evaluate their relationship with the duration of QT interval in patients with acute coronary syndrome.

Materials and methods. In a random manner, the findings of a 24-hour ECG Holter monitoring of 104 patients with baseline sinus rhythm ( 37 women and 67 men, the average age $69 \pm 11$ years: women $72 \pm 11$, men $68 \pm 12$ ) who were treated for ACS (MI with ST-segment elevation, MI without ST-segment elevation, unstable angina)were selected and processed. Patients with ACS were provided medical care according to the unified clinical protocol of emergency, primary, secondary (specialized), tertiary (highly specialized) medical care and medical rehabilitation of acute coronary syndrome without ST segment elevation(order No. 164 of the Ministry of Health of Ukraine dated March 03, 2016) and unified clinical protocol of emergency, primary, secondary (specialized) and tertiary (highly specialized) medical care and medical rehabilitation of acute coronary syndrome with ST segment elevation (order No. 455 of the Ministry of Health of Ukraine dated July 03, 2014).

Patients were divided into 3 study groups: patients with MI with ST segment elevation (experimental group1 - EG1), with MI without ST segment elevation (EG2) and with unstable angina (EG3). The control group (CG) was formed by practically healthy patients of the same age and sex with the experimental ones

10 Анікєєва Т.В., Воробйов А.С. Інструментальні та лабораторні можливості оцінки структурно-функціонального стану міокарда у пацієнтів 3 постінфарктним кардіосклерозом. Кровообіг та гемостаз. 2013. № 2. С. 34.

${ }_{11}$ Індика С., Ягенський А., Духневич Л. Варіабельність серцевого ритму у хворих після інфаркту міокарда на амбулаторному етапі реабілітації. Молода спортивна наука Украӥни. 2011. № 3. С. 139-140. 
(32 individuals). The ECG was monitored for 2 days using a Holter ECG system (Holter system of ECG of LABTECH Ltd).

During the examination the total number of heartbeats per day, minimum, maximum, minimum average minute, maximum average minute and average heart rate were evaluated; the average (avg QT), average corrected (avg QTc), maximum (max QT) and maximum corrected (max QTc), the duration of the QT interval; frequency (SDNN, SDNN index, rMSDD, pNN50) and spectral (RR triangle, HF, LF, VLF) HRV characteristicshave been recommended by the European Union of Cardiology and the North American Union of Cardiac Stimulation and Electrophysiology.

Table 1

Total heart rate per day, minimum, maximum, minimum average minutes, maximum average minutes and daily heart rate during 24-hour ECG Holter monitoring in patients of the control group

\begin{tabular}{|l|c|}
\hline \multicolumn{1}{|c|}{ Indicator } & Value \\
\hline Total heart rate & $114294 \pm 11458$ \\
\hline mean HR & $73,0 \pm 9,0$ \\
\hline max. HR & $151,0 \pm 18,5$ \\
\hline min. HR & $53,0 \pm 2,0$ \\
\hline max. HR minute & $148,0 \pm 12,5$ \\
\hline min. HR minute & $550 \pm 2,5$ \\
\hline
\end{tabular}

The supraventricular and ventricular extrasystoles have been evaluated for the presence of isolated extrasystoles, couplets, bigemenias, trigemenias, runs.

Table 2

Indicators of supraventricular and ventricular disorders during 24-hour Holter ECG monitoring in patients of the control group

\begin{tabular}{|l|c|c|}
\hline \multicolumn{1}{|c|}{ Indicator } & $\begin{array}{c}\text { Extraventricular } \\
\text { extrasystole }\end{array}$ & $\begin{array}{c}\text { Ventricular } \\
\text { extrasystole }\end{array}$ \\
\hline Isolated extrasystoles & $243,0 \pm 29,0$ & $86,0 \pm 140$ \\
\hline Couplets & $21,0 \pm 9,0$ & 0 \\
\hline Bigeminia & $13,0 \pm 4,0$ & $9,0 \pm 2,0$ \\
\hline Trigeminia & $26,0 \pm 10,0$ & $15,0 \pm 2,0$ \\
\hline Runs & 0 & 0 \\
\hline
\end{tabular}


Table 3

The value of the QT interval during the 24-hour Holter ECG monitoring in patients of the control group

\begin{tabular}{|c|c|}
\hline Indicator & Value \\
\hline max QT & $375.0 \pm 24,0$ \\
\hline max QTc & $388.0 \pm 16,0$ \\
\hline avg QT & $365.0 \pm 24,0$ \\
\hline avg QTc & $386.0 \pm 12,0$ \\
\hline
\end{tabular}

Standard deviation of NN-intervals (SDNN) is the square root of the spread of these intervals (for evaluation of total HRV) and indicators calculated by inter-interval differences (rMSSD - square root of the mean square of the difference between adjacent $\mathrm{NN}$-intervals (for evaluation of high-frequency components), pNN50 is the proportion of the number of intervals between adjacent $\mathrm{NN}$ intervals exceeding $50 \mathrm{~ms}$ to the total number of NN intervals in the HRV record). All these indices reflect fast highfrequency oscillations in the structure of HRV and are strongly correlated with each other and with similar spectral characteristics.

Table 4

Values of HRV frequency characteristics during 24-hour Holter ECG monitoring in patients of the control group

\begin{tabular}{|c|c|}
\hline Indicator & Value \\
\hline SDNN & $122,5 \pm 16,4$ \\
\hline SDNN індекс & $54,2 \pm 16,2$ \\
\hline rMSDD & $28,7 \pm 7,4$ \\
\hline pNN 50 & $5,0 \pm 3,2$ \\
\hline
\end{tabular}

When estimating the power of oscillations of the heart rhythm, a component of very low VLF frequencies was selected $(0,003-0,04 \mathrm{~Hz})-$ reflects humoral effects on the heart rhythm, low LF frequencies $(0,04-0,15 \mathrm{~Hz})$ - mainly reflects the influence of the sympathetic nervous system on the heart rate, high HFfrequency $(0,15-0,40 \mathrm{~Hz})-$ reflects the influence of the parasympathetic part of the ANS on the heart rate, the power distribution and the central frequency of each component are not fixed, may vary due to changes in autonomic modulation of the cardiac cycle.

The monitoring time was 24 hours. The values of the studied parameters are presented in the form $\mathrm{M}+/-\mathrm{m}$, where $\mathrm{M}$ is the arithmetic mean, $\mathrm{m}$ is the standard deviation. The t-criterion (statistically significant considered difference $\mathrm{p}<0,05$ ) was used in the analysis of the obtained indicators and 
the Pearson correlation coefficient (r) was used to estimate the significance and density of the linear relation, the parameters of the regression equation were determined by the method of the least quadrants.

Table 5

Values of HRV spectral characteristics during 24-hour Holter ECG monitoring in patients of the control group

\begin{tabular}{|c|c|}
\hline Indicator & Value \\
\hline RR triangle & $14.2 \pm 2.4$ \\
\hline VLF & $2553,3 \pm 536,7$ \\
\hline HF & $312,3 \pm 151,2$ \\
\hline LF & $725,3 \pm 376,3$ \\
\hline LF/HF & $2,3 \pm 1,2$ \\
\hline
\end{tabular}

\section{Characteristics of indicators of Holter ECG monitoring, indicators} of heart rate variability in patients with acute coronary syndrome While analyzing Holter ECG monitoring, the total heart rate in all three study groups did not differ significantly from the control group $(\mathrm{p}<0.05)$.

Table 6

Total heart rate per day, minimum, maximum, minimum average minutes, maximum average minutes and daily heart rate during

24-hour ECG Holter monitoring in patients with acute coronary syndrome

\begin{tabular}{|l|c|c|c|}
\hline \multicolumn{1}{|c|}{ Indicator } & EG1 & EG3 & EG3 \\
\hline Total heart rate & $123635 \pm 12968$ & $114294 \pm 11458$ & $128545 \pm 9878$ \\
\hline mean HR & $81,0 \pm 7,0$ & $79,0 \pm 12,0$ & $83,0 \pm 14,0$ \\
\hline max. HR & $148,0 \pm 16,0$ & $155,0 \pm 12,0$ & $156,0 \pm 18,0$ \\
\hline min. HR & $51,0 \pm 3,0$ & $49,0 \pm 2,0$ & $48,0 \pm 3,0$ \\
\hline max. HR minute & $144,0 \pm 11,0$ & $152,0 \pm 10,0$ & $153,0 \pm 18,0$ \\
\hline min. HR minute & $54,0 \pm 3,0$ & $50,0 \pm 2,0$ & $51,0 \pm 3,0$ \\
\hline
\end{tabular}

During the analysis of the average daily heart rate, no statistically significant difference was found in patients in all three experimental groups compared with the control and between themselves $(p>0.05)$, but the highest number was found in patients ofEG3 ( $83.0 \pm 14.0$ beats / min), and in EG1 and EG2 were respectively $81.0 \pm 7.0$ and $79.0 \pm 12.0$ beats / min. The maximum and minimum heart rates in EG3 were $156.0 \pm 18.0$ and 
$48.0 \pm 3.0$ respectively, in EG1 the maximum heart rate was $1148.0 \pm 16.0$ and the minimum heart rate was $51.0 \pm 3.0$ beats / min. The mean values of maximum and minimum heart rate in EG 2 were $155.0 \pm 12.0$ beats / min, and minimum heart rate $-49.0 \pm 2.0$ beats / min. That is, the highest mean value of maximum heart rate was observed in EG3, the highest mean value of the minimum heart rate was found in EG1 and conversely the lowest mean value of the maximum heart rate was found in EG1 and the lowest average value of the minimum heart rate was found in EG3. The similar pattern was observed during the analysis of the heart-rate indicators of the heart rate and no statistical differences between the experimental groups and the control one were revealed.

Table 7

Indicators of supraventricular disorders during 24-hour Holter ECG monitoring in patients with acute coronary syndrome

\begin{tabular}{|l|c|c|c|}
\hline \multicolumn{1}{|c|}{ Indicator } & EG1 & EG3 & EG3 \\
\hline $\begin{array}{l}\text { Isolated } \\
\text { extrasystoles }\end{array}$ & $988.0 \pm 75.0$ & $1257.0 \pm 129.0$ & $1206.0 \pm 96.0$ \\
\hline Couplets & $378.0 \pm 88.0$ & $204.0 \pm 95.0$ & $124.0 \pm 57.0$ \\
\hline Bigeminia & $317.0 \pm 92.0$ & $286.0 \pm 84.0$ & $154.0 \pm 47.0$ \\
\hline Trigeminia & $425.0 \pm 72.0$ & $417.0 \pm 68.0$ & $234.0 \pm 80.0$ \\
\hline Runs & $25.0 \pm 12.0$ & $14.0 \pm 6.0$ & $9.0 \pm 2.0$ \\
\hline
\end{tabular}

During the assessment of supraventricular disorders, the number of isolated supraventricular extrasystoles in patients of EG2 1257.0 \pm 129.0 $(\mathrm{p}<0.05)$ was found to be significantly higher in comparison with the control group, in EG1 this number was $988.0 \pm 75.0(\mathrm{p}<0.05)$ and in EG3 $1206.0 \pm 96.0 \quad(p<0.05)$. Also significant $(p<0.05)$ for all three experimental groups as compared to the control one there was a number of vertebrate extrasystoles couplets and in EG1, EG2 and EG3 were: $378,0 \pm 88,0,204,0 \pm 95,0$ and $124.0 \pm 57.0$ respectively. Higher ventricular extrasystoles were dominant in EG1 - $317.0 \pm 92.0$ (p < 0.05 vs. KG), in EG2 - 286.0 $\pm 84.0(\mathrm{p}<0.05)$ and the lowest in EG3 - 154.0 \pm 47.0 $(\mathrm{p}<0.05)$. Similarly, for supraventricular trigeminae, the highest mean value was recorded in EG1 $-425.0 \pm 72.0$ which was slightly different from EG2 $417.0 \pm 68.0$ and in EG3 $-234.0 \pm 80.0$ ( $\mathrm{p}<0.05$ for all study groups as compared to CG). $25.0 \pm 12.0$ supraventricular runs were detected in EG1, $14.0 \pm 6.0$ in EG2 and $9.0 \pm 2.0$ in EG3, while in the control group they were not detected. 
Table 8

Indicators of ventricular disorders during 24-hour Holter ECG monitoring in patients with acute coronary syndrome

\begin{tabular}{|l|c|c|c|}
\hline \multicolumn{1}{|c|}{ Indicator } & EG1 & EG3 & EG3 \\
\hline $\begin{array}{l}\text { Isolated } \\
\text { extrasystoles }\end{array}$ & $793.0 \pm 102.0$ & $704.0 \pm 93.0$ & $598.0 \pm 122.0$ \\
\hline Couplets & $114.0 \pm 42.0$ & $88.0 \pm 41.0$ & $24.0 \pm 12.0$ \\
\hline Bigeminia & $129.0 \pm 43.0$ & $65.0 \pm 30.0$ & $68.0 \pm 31.0$ \\
\hline Trigeminia & $189.0 \pm 41.0$ & $48.0 \pm 21.0$ & $37.0 \pm 14.0$ \\
\hline Runs & 2.0 & 1.0 & 0 \\
\hline
\end{tabular}

The highest number of isolated ventricular extrasystoles in patients of EG1 was found $-793.0 \pm 102.0$, the lowest number was found in EG3 $598.0 \pm 122.0$ and in EG2 it was 704.0 \pm 93.0 (compared with the controlgroup their number was significantly different for all three study groups). The number of couplets in EG1, DG2 and EG3 were respectively $114.0 \pm 42.0,88.0 \pm 41.0$ and $24.0 \pm 12.0$, but they were not detected at all in the control group. Ventricular extrasystole biochemistry was the highest in EG1129.0 \pm 43.0 and the lowest in EG2 $65.0 \pm 30.0$ and in EG 3 it was $68.0 \pm 31.0(\mathrm{p}<0.05$ for all experimental groups in comparison with the control group). There was also a significant difference in the presence of ventricular trigemina in all experimental groups compared with the control one, where the highest mean value was found in EG1 - 189.0 \pm 41.0 and the lowest in EG3 - 37.0 \pm 14.0 , in EG2 - 48.0 \pm 21.0 . Ventricular runs were not detected in the control group as well as in EG3. 2 cases were found in $\mathrm{EG} 1$ and one case in EG2 respectively.

Table 9

Values of HRV frequency characteristics during 24-hour Holter ECG monitoring in patients with acute coronary syndrome

\begin{tabular}{|l|c|c|c|}
\hline \multicolumn{1}{|c|}{ Indicator } & EG1 & EG3 & EG3 \\
\hline SDNN & $92.9 \pm 17.4$ & $97.2 \pm 15.0$ & $104.7 \pm 18.2$ \\
\hline SDNN index & $34.9 \pm 14.3$ & $35.9 \pm 14.8$ & $38.8 \pm 12.4$ \\
\hline rMSDD & $23.3 \pm 5.7$ & $26.0 \pm 6.6$ & $27.6 \pm 7.7$ \\
\hline pNN 50 & $18.4 \pm 4.4$ & $14.9 \pm 4.8$ & $10.2 \pm 5.7$ \\
\hline
\end{tabular}

The analysis of HRV frequency indices revealed a decrease in SDNN for all three experimental groups as compared to the control one with its highest value in EG3 $104.7 \pm 18.2$ and in EG1 and EG2 it was respectively $92.9 \pm 17.4$ and $97,2 \pm 15.0$. The SDNN index was similar for EG1, EG2 
and EG3 $-34.9 \pm 14.3,35.9 \pm 14.8$ and $38.8 \pm 12.4$. rMSDD was also the highest in EG3 - 27.6 \pm 7.7 and in EG1 and EG2 were $23.3 \pm 5.7$ and $26.0 \pm 6.6$ respectively. The highest pNN50 was observed in EG1 $18.4 \pm 4.4$ and the lowest in EG $3-10.2 \pm 5.7$, in EG2 it was $14.9 \pm 4.8$.

The analysis of the frequency characteristics of HRV revealed a significant difference for the SDNN, SDNN index ( $p<0.01$ versus CG), but no significant difference was found for $\operatorname{rMSDD}(\mathrm{p}>0.05)$ and $\mathrm{pNN50}$ $(\mathrm{p}>0.05)$.

Table 10

Values of HRV spectral characteristics during 24-hour Holter ECG monitoring in patients with acute coronary syndrome

\begin{tabular}{|l|c|c|c|}
\hline \multicolumn{1}{|c|}{ Indicator } & EG1 & EG3 & EG3 \\
\hline RR triangle & $3.4 \pm 1.4$ & $6.5 \pm 2.5$ & $9.4 \pm 1.9$ \\
\hline VLF & $1658.9 \pm 349.9$ & $1824.6 \pm 361.9$ & $1944.6 \pm 322.7$ \\
\hline HF & $136.8 \pm 70.1$ & $196.8 \pm 75.3$ & $202.6 \pm 68.1$ \\
\hline LF & $463.6 \pm 92.0$ & $620.1 \pm 64.8$ & $650.0 \pm 102.8$ \\
\hline LF/HF & $3.4 \pm 1.5$ & $3.2 \pm 1.6$ & $3.2 \pm 1.4$ \\
\hline
\end{tabular}

When calculating the HRV spectral indices, the highest RR triangle was detected in G3 $(9.4 \pm 1.9)$, which was 1.5 times lower than the same indicator of the control group and was decreased in EG1 and EG2 more than 2 times and amounted to $3.4 \pm 1.4$ and $6.5 \pm 2.5$ respectively. Compared with the control group, VLF in EG3 was $23.8 \%$ was lower, but its mean absolute value $(1658.9 \pm 349.9)$ was the highest among all experimental groups and the lowest in EG $11658.9 \pm 349,9$ and $35.1 \%$ different from the control group. HF was the highest in EG3 $202.6 \pm 68.1$ and the lowest in EG1 $136.8 \pm 70.1$, in EG2 $196.8 \pm 75.3$. LF in EG3 was also the highest $650.0 \pm 102.8$ and the lowest in EG1 $463.6 \pm 92.0$ and in EG2 $620.1 \pm 64.8$. However, taking into consideration the reduced overall variability in EG1 and EG2 in comparison with EG3 such a distribution of $\mathrm{HF}$ and LF is natural.

The LF / HF ratio was calculated according to the low and high wavelength spectral for HRV ratios, significantly ( $p<0.05$ versus $C G)$ the highest values were found in EG1 (3.4 \pm 1.5$)$, which is $5.9 \%$ more than in EG2 and EG3 and is $3.2 \pm 1.6$ and $3.2 \pm 1.4$ as compared with the control group for LF / HF, the preference was significant for all groups $(\mathrm{p}<0.05)$.

The analysis of the spectral characteristics of HRV indicates a significant difference for HF $(p<0.05)$, LF ( $p<0.01)$, VLF $(p<0.01)$ for all three study groups compared to the control one. This indicates an over-activation of the autonomic nervous system in patients with ACS. 
The value of the QT interval during the 24-hour Holter ECG monitoring in patients with acute coronary syndrome

\begin{tabular}{|l|c|c|c|}
\hline \multicolumn{1}{|c|}{ Indicator } & EG1 & EG3 & EG3 \\
\hline max QT & $478.5 \pm 26.9$ & $465.5 \pm 37.0$ & $445.9 \pm 28.8$ \\
\hline max QTc & $455.1 \pm 24.2$ & $451.6 \pm 29.8$ & $435.1 \pm 27.6$ \\
\hline avg QT & $398.5 \pm 33.4$ & $400.7 \pm 32.2$ & $388.5 \pm 33.4$ \\
\hline avg QTc & $404.8 \pm 28.8$ & $410.8 \pm 23.1$ & $387.2 \pm 19.2$ \\
\hline
\end{tabular}

During the analysis of the duration of the QT interval, its maximum elongation in G1 $(478.5 \pm 26.9)$ was revealed, and in EG 2 and EG3 it was $478.5 \pm 26.9$ and $445.9 \pm 28.8$ respectively, which was reflected in the calculation of the maximum corrected QTc, where this indicator was also found to be the highest in EG $1455.1 \pm 24.2$, although in EG 2 its value differed slightly $451,6 \pm 29,8$, in EG 3 it was $435.1 \pm 27.6$. The mean QT value was the highest in EG2 $(400.7 \pm 32.2)$ and the lowest in EG3 $(388.5 \pm 33.4)$, in EG1 it was $398.5 \pm 33.4$, which in EG1, EG2 and EG3 $8.3 \%, 8.8 \%$ and $6.0 \%$ it differed from the control group. The highest corrected mean QT was also found in EG2 $(410.8 \pm 23.1)$ which was slightly different from the similar indicator in EG1 $(404.8 \pm 28.8)$ and in EG3 it was $387.2 \pm 19.2$.

The analysis of the duration of the QT interval did not reveal a statistically significant difference between the maximum QT index $(p>0.05)$, the maximum corrected QT index $(p>0.05)$, the average QT index $(p>0.05)$, and the average corrected QT index $(p>0.05)$ for the study groups and the control group.

\section{Relationship indicators of Holter ECG monitoring and indicators of heart rate variability with the duration of QT interval in patients with acute coronary syndrome}

A significant $(p<0.05)$ moderate strength positive correlation was found between the mean and corrected QT mean and the presence of isolated supraventricular extrasystoles in patients of EG1 $(+0.62$ and + 0.49 respectively). A significant $(\mathrm{p}<0.05)$ mean strength of the relationship between the maximal corrected, mean, and mean corrected QT values and the number of supraventricular couplets in patients of EG1 was also revealed. For supraventricular bohemia, the relationship was positively weak but not reliable for all indicators of QT interval in EG1 ( $p>0.05)$. For supraventricular trigemina, only the maximum value of QT in EG1 was positive and reliable, for other indicators of the QT interval the relationship was not reliable $(\mathrm{p}>0.05)$. 
Table 12

Relationship supraventricular disorders with the duration of QT interval in patients EG1

\begin{tabular}{|l|c|c|c|c|}
\hline \multicolumn{1}{|c|}{ Indicator } & $\max$ QT & $\max$ QTe & avg QT & avg QTc \\
\hline Isolated extrasystoles & $\begin{array}{c}0.50 \# \\
\mathrm{t}=1.7\end{array}$ & $\begin{array}{c}0.37 \# \\
\mathrm{t}=1.9\end{array}$ & $\begin{array}{c}0.62^{*} \\
\mathrm{t}=2.3\end{array}$ & $\begin{array}{c}0.49^{*} \\
\mathrm{t}=2.2\end{array}$ \\
\hline Couplets & $0.25 \#$ & $0.35^{*}$ & $0.36^{*}$ & $0.33^{*}$ \\
& $\mathrm{t}=1.1$ & $\mathrm{t}=2.5$ & $\mathrm{t}=2.4$ & $\mathrm{t}=2.3$ \\
\hline Bigeminia & $0.12 \#$ & $0.14 \#$ & $0.22 \#$ & $0.19 \#$ \\
& $\mathrm{t}=0.2$ & $\mathrm{t}=0.3$ & $\mathrm{t}=1.3$ & $\mathrm{t}=1.2$ \\
\hline Trigeminia & $0.61 *$ & $0.29 \#$ & $0.27 \#$ & $0.23 \#$ \\
& $\mathrm{t}=2.6$ & $\mathrm{t}=1.0$ & $\mathrm{t}=1.2$ & $\mathrm{t}=0.9$ \\
\hline
\end{tabular}

Note: $*-\mathrm{p}<0.05 ; * *-\mathrm{p}<0.01 ; \#-\mathrm{p}>0.05$

Table 13

Relationship supraventricular disorders with the duration of QT interval in patients EG2

\begin{tabular}{|l|c|c|c|c|}
\hline \multicolumn{1}{|c|}{ Indicator } & $\max$ QT & $\max$ QTe & avg QT & avg QTc \\
\hline Isolated & $\begin{array}{c}0.23 \# \\
\mathrm{t}=0.8\end{array}$ & $\begin{array}{c}0.28 \# \\
\mathrm{t}=0.8\end{array}$ & $\begin{array}{c}0.32^{*} \\
\mathrm{t}=2.0\end{array}$ & $\begin{array}{c}0.32^{*} \\
\mathrm{t}=2.2\end{array}$ \\
\hline Couptrasystoles & $\begin{array}{c}0.30 \# \\
\mathrm{t}=1.1\end{array}$ & $\begin{array}{c}0.31 \# \\
\mathrm{t}=1.8\end{array}$ & $\begin{array}{c}0.38^{*} \\
\mathrm{t}=2.1\end{array}$ & $\begin{array}{c}0.34^{*} \\
\mathrm{t}=2.3\end{array}$ \\
\hline Bigeminia & $\begin{array}{c}0.19 \# \\
\mathrm{t}=1.0\end{array}$ & $\begin{array}{c}0.21 \# \\
\mathrm{t}=1.1\end{array}$ & $\begin{array}{c}0.32^{*} \\
\mathrm{t}=2.8\end{array}$ & $\begin{array}{c}0,30^{*} \\
\mathrm{t}=2.2\end{array}$ \\
\hline Trigeminia & $\begin{array}{c}0.19 \# \\
\mathrm{t}=0.6\end{array}$ & $\begin{array}{c}0.19 \# \\
\mathrm{t}=1.1\end{array}$ & $\begin{array}{c}0.14 \# \\
\mathrm{t}=1.9\end{array}$ & $\begin{array}{c}0.21 \# \\
\mathrm{t}=1.9\end{array}$ \\
\hline
\end{tabular}

Note: ${ }^{*}-\mathrm{p}<0.05 ; *^{*}-\mathrm{p}<0.01 ; \#-\mathrm{p}>0.05$

The positive correlation was found for the mean strength for the mean and the mean corrected QT and the presence of supraventricular isolated extrasystoles, supraventricular couplet, and bigemenias ( $p<0.05)$ in EG2. For the rest of the indicators in this group, the relationship is positive but minor for bigamy, trigemina, and isolated supraventricular extrasystoles $(p>0.05)$ and positive mean strength for supraventricular extrasystoles $(\mathrm{p}>0.05)$. 
Relationship supraventricular disorders with the duration of QT interval in patients EG3

\begin{tabular}{|l|c|c|c|c|}
\hline \multicolumn{1}{|c|}{ Indicator } & $\max$ QT & $\max$ QTe & avg QT & avg QTc \\
\hline Isolated extrasystoles & $0.49^{* *}$ & $0.42^{* *}$ & $0.38^{*}$ & $0.38^{*}$ \\
& $\mathrm{t}=3.8$ & $\mathrm{t}=3.2$ & $\mathrm{t}=2.7$ & $\mathrm{t}=2.6$ \\
\hline Couplets & $0.21 \#$ & $0.25 \#$ & $0.18^{*}$ & $0.19^{*}$ \\
& $\mathrm{t}=1.4$ & $\mathrm{t}=1.7$ & $\mathrm{t}=2.2$ & $\mathrm{t}=2.4$ \\
\hline Bigeminia & $0.54 \#$ & $0.44 \#$ & $0.29 *$ & $0.30^{*}$ \\
& $\mathrm{t}=1.3$ & $\mathrm{t}=1.5$ & $\mathrm{t}=2.9$ & $\mathrm{t}=2.9$ \\
\hline Trigeminia & $0.08 \#$ & $0.13 \#$ & $0.11 \#$ & $0.17 \#$ \\
& $\mathrm{t}=1.4$ & $\mathrm{t}=1.1$ & $\mathrm{t}=0.9$ & $\mathrm{t}=0.7$ \\
\hline
\end{tabular}

Note: $*-p<0.05 ; * *-p<0.01 ; \#-p>0.05$

The positive mean strength correlation was found between isolated supraventricular extrasystoles and supraventricular bohemia $(\mathrm{p}>0.05)$ also positive $(p>0.05)$, but a minor relationship was found between supraventricular couplets and mean and mean corrected QT in EG3. For other indicators, the relationship was not reliable $(\mathrm{p}>0.05)$.

Table 15

Relationship ventricular disorders with the duration of QT interval in patients EG1

\begin{tabular}{|l|c|c|c|c|}
\hline \multicolumn{1}{|c|}{ Indicator } & $\max$ QT & $\max$ QTe & avg QT & avg QTc \\
\hline Isolated extrasystoles & $0.37^{*}$ & $0.36^{*}$ & $0.44^{*}$ & $0.45^{*}$ \\
& $\mathrm{t}=3.6$ & $\mathrm{t}=2.5$ & $\mathrm{t}=2.3$ & $\mathrm{t}=2.2$ \\
\hline Couplets & $0.31^{*}$ & $0.28^{*}$ & $0.31^{*}$ & $0.32^{*}$ \\
& $\mathrm{t}=2.1$ & $\mathrm{t}=2.4$ & $\mathrm{t}=2.5$ & $\mathrm{t}=2.3$ \\
\hline Bigeminia & $0.27^{*}$ & $0.24^{*}$ & $0.22^{*}$ & $0.24^{*}$ \\
& $\mathrm{t}=2.5$ & $\mathrm{t}=2.2$ & $\mathrm{t}=2.3$ & $\mathrm{t}=2.2$ \\
\hline Trigeminia & $0.17^{*}$ & $0.15 \#$ & $0.24^{*}$ & $0.28 \#$ \\
& $\mathrm{t}=2.4$ & $\mathrm{t}=1.8$ & $\mathrm{t}=2.2$ & $\mathrm{t}=9.9$ \\
\hline
\end{tabular}

Note: $*-p<0.05 ; * *-p<0.01 ; \#-p>0.05$

For EG1, the mean strength of positive correlation was found for all ventricular disorders $(p<0.05)$ except for ventricular trigemina, as this correlation was found to be unreliable for maximal corrected and mean corrected QT ( $p>0.05)$. 
Relationship ventricular disorders with the duration of QT interval in patients EG2

\begin{tabular}{|l|c|c|c|c|}
\hline \multicolumn{1}{|c|}{ Indicator } & max QT & max QTc & avg QT & avg QTc \\
\hline Isolated & $0.26^{*}$ & $0.26^{*}$ & $0.25^{*}$ & $0.26^{*}$ \\
extrasystoles & $\mathrm{t}=2.8$ & $\mathrm{t}=2.7$ & $\mathrm{t}=2.9$ & $\mathrm{t}=2.5$ \\
\hline Couplets & $0.34^{*}$ & $0.30^{*}$ & $0.32^{*}$ & $0.32^{*}$ \\
& $\mathrm{t}=2.5$ & $\mathrm{t}=2.8$ & $\mathrm{t}=2.2$ & $\mathrm{t}=2.1$ \\
\hline Bigeminia & $0.27^{*}$ & $0.25 \#$ & $0.29^{*}$ & $0.28^{*}$ \\
& $\mathrm{t}=2.1$ & $\mathrm{t}=1.2$ & $\mathrm{t}=2.2$ & $\mathrm{t}=2.0$ \\
\hline Trigeminia & $0.12 \#$ & $0.10 \#$ & $0.19 \#$ & $0.14 \#$ \\
& $\mathrm{t}=0.8$ & $\mathrm{t}=0.5$ & $\mathrm{t}=1.0$ & $\mathrm{t}=1.1$ \\
\hline
\end{tabular}

Note: $*-p<0.05 ; * *-p<0.01 ; \#-p>0.05$

For EG2, a positive minor strength relationship was observed between isolated ventricular extrasystoles and all QT intervals $(\mathrm{p}<0.05)$. For ventricular couplets, the relationship was significantly positive mean strength for all QT interval indicators. Ventricular bigemia was significantly correlated with maximal, mean and mean corrected QT $(\mathrm{p}<0.05)$ and the relationship between them was low. Ventricular trigemina did not significantly correlate with all QT scores in this group.

Table 17

\section{Relationship ventricular disorders with the duration of QT interval in patients EG3}

\begin{tabular}{|l|c|c|c|c|}
\hline \multicolumn{1}{|c|}{ Indicator } & max QT & max QTc & avg QT & avg QTc \\
\hline Isolated & $0.26^{*}$ & $0.23^{*}$ & $0.27^{*}$ & $0.23^{*}$ \\
extrasystoles & $\mathrm{t}=2.3$ & $\mathrm{t}=2.2$ & $\mathrm{t}=2.4$ & $\mathrm{t}=2.2$ \\
\hline Couplets & $0.25 \#$ & $0.29^{*}$ & $0.28^{*}$ & $0.27^{*}$ \\
& $\mathrm{t}=1.7$ & $\mathrm{t}=2.7$ & $\mathrm{t}=2.8$ & $\mathrm{t}=2.6$ \\
\hline Bigeminia & $0.34 \#$ & $0.32^{*}$ & $0.25^{*}$ & $0.28^{*}$ \\
& $\mathrm{t}=1.4$ & $\mathrm{t}=2.5$ & $\mathrm{t}=2.4$ & $\mathrm{t}=2.7$ \\
\hline Trigeminia & $0.16 \#$ & $0.16 \#$ & $0.18 \#$ & $0.21 \#$ \\
& $\mathrm{t}=1.4$ & $\mathrm{t}=1.4$ & $\mathrm{t}=1.5$ & $\mathrm{t}=1.2$ \\
\hline
\end{tabular}

Note: ${ }^{*}-\mathrm{p}<0.05 ; * *-\mathrm{p}<0.01 ; \#-\mathrm{p}>0.05$

For EG3, a significant positive minor relationship for ventricular extrasystoles and all indicators of the QT interval ( $p<0.05)$ was detected. The number of ventricular couplets was significantly correlated with all QT indicators, the relationship was low positive and unreliable only for maximum QT. Ventricular bigemia correlated significantly with all QT 
indices except the maximum QT, the relationship was positive with average force only for the maximum corrected QT, with the remaining QT intervals being positive but of low strength. Ventricular trigemenias did not significantly correlate with QT indices in EG3.

Table 18

Relationship HRV frequency characteristics with the duration of QT interval in patients EG1

\begin{tabular}{|l|l|l|l|l|}
\hline \multicolumn{1}{|c|}{ Indicator } & \multicolumn{1}{c|}{ SDNN } & SDNN index & \multicolumn{1}{c|}{ rMSSD } & pNN 50\% \\
\hline max QT & $0.54^{* *}$ & $0.59^{* *}$ & $0.50 \#$ & $0.39^{* *}$ \\
& $\mathrm{t}=6.2$ & $\mathrm{t}=7.0$ & $\mathrm{t}=1.3$ & $\mathrm{t}=7.9$ \\
\hline max QTc & $0.38 \#$ & $0.38 \#$ & $0.21^{* *}$ & $0.16^{* *}$ \\
& $\mathrm{t}=1.1$ & $\mathrm{t}=1.6$ & $\mathrm{t}=3.2$ & $\mathrm{t}=5.7$ \\
\hline avg QT & $0.49^{*}$ & $0.55^{* *}$ & $0.54^{*}$ & $0.48^{* *}$ \\
& $\mathrm{t}=2.9$ & $\mathrm{t}=8.5$ & $\mathrm{t}=2.1$ & $\mathrm{t}=5.1$ \\
\hline avg QTc & $0.25^{* *}$ & $0.21^{*}$ & $0.20^{* *}$ & $0.18^{* *}$ \\
& $\mathrm{t}=6.8$ & $\mathrm{t}=2.7$ & $\mathrm{t}=3.5$ & $\mathrm{t}=6.8$ \\
\hline
\end{tabular}

Note: $*-\mathrm{p}<0.05 ; * *-\mathrm{p}<0.01 ; \#-\mathrm{p}>0.05$

A direct significant relationship was found between SDNN index, SDNN, pNN 50\% and maximum QT $(\mathrm{p}<0.01)$. For the highest QT-corrected positive and significant $(\mathrm{p}<0.01)$, however, a weak relationship with rMSSD pNN was found in 50\%. The relationship for mean QT of mean corrected QT was found to be reliable for all HRV frequency in EG1, however, for the mean value, the mean strength relationship, for the medium-corrected QT, the relationship was weak.

Table 19

Relationship HRV frequency characteristics with the duration of QT interval in patients EG2

\begin{tabular}{|l|l|l|l|l|}
\hline \multicolumn{1}{|c|}{ Indicator } & \multicolumn{1}{|c|}{ SDNN } & SDNN index & \multicolumn{1}{|c|}{ rMSSD } & pNN 50\% \\
\hline max QT & $0.57^{* *}$ & $0.49^{* *}$ & $0.45^{* *}$ & $0.30^{*}$ \\
& $\mathrm{t}=3.2$ & $\mathrm{t}=3.1$ & $\mathrm{t}=3.3$ & $\mathrm{t}=2.3$ \\
\hline max QTc & $0.32 \#$ & $0.22 \#$ & $0.41^{*}$ & $0.1^{*}$ \\
& $\mathrm{t}=1.2$ & $\mathrm{t}=1.6$ & $\mathrm{t}=2.2$ & $\mathrm{t}=2.7$ \\
\hline avg QT & $0.29^{*}$ & $0.28^{*}$ & $0.29^{*}$ & $0.28^{* *}$ \\
& $\mathrm{t}=2.5$ & $\mathrm{t}=2.2$ & $\mathrm{t}=2.6$ & $\mathrm{t}=3.1$ \\
\hline avg QTc & $0.22^{*}$ & $0.27^{*}$ & $0.28^{*}$ & $0.20^{*}$ \\
& $\mathrm{t}=2.7$ & $\mathrm{t}=2.3$ & $\mathrm{t}=2.5$ & $\mathrm{t}=2.8$ \\
\hline
\end{tabular}

Note: $*-p<0.05 ; * *-p<0.01 ; \#-p>0.05$ 
In EG2, a significant positive mean strength was found between the maximum QT and all HRV frequencies. For the highest QT correction, the relationship was only valid for rMSSD and $\mathrm{pNN}$ in 50\%. For mean and mean corrected was reliable positive weak strength for all HRV frequencies.

Table 20

Relationship HRV frequency characteristics with the duration of QT interval in patients EG3

\begin{tabular}{|l|l|l|l|l|}
\hline \multicolumn{1}{|c|}{ Indicator } & \multicolumn{1}{c|}{ SDNN } & SDNN index & rMSSD & pNN 50\% \\
\hline max QT & $0.32^{*}$ & $0.33^{*}$ & $0.55^{*}$ & $0.31^{*}$ \\
& $\mathrm{t}=2.7$ & $\mathrm{t}=2.2$ & $\mathrm{t}=2.4$ & $\mathrm{t}=2.1$ \\
\hline max QTc & $0.32 \#$ & $0.22 \#$ & $0.28 \#$ & $0.30 \#$ \\
& $\mathrm{t}=1.2$ & $\mathrm{t}=1.6$ & $\mathrm{t}=1.2$ & $\mathrm{t}=1.7$ \\
\hline avg QT & $0.24 \#$ & $0.29 \#$ & $0.42^{*}$ & $0.37 *$ \\
& $\mathrm{t}=1.6$ & $\mathrm{t}=1.4$ & $\mathrm{t}=2.5$ & $\mathrm{t}=2.9$ \\
\hline avg QTc & $0.42^{*}$ & $0.44^{*}$ & $0.32 \#$ & $0.19 \#$ \\
& $\mathrm{t}=2.1$ & $\mathrm{t}=2.3$ & $\mathrm{t}=1.3$ & $\mathrm{t}=1.1$ \\
\hline
\end{tabular}

Note: $*-\mathrm{p}<0.05 ; * *-\mathrm{p}<0.01 ; \#-\mathrm{p}>0.05$

In EG3, a significant positive mean relationship strength was found between the maximum QT and all HRV frequencies. No reliable relationship was found for QT correction. The mean QT value correlates significantly with rMSSD and pNN in 50\%, the relationship of this average strength. The positive mean relationship strength was between the mean QT and the SDNN, SDNN index and among other HRV frequency ratios the relationship was found to be unreliable.

Table 21

Relationship HRV spectral characteristics with the duration of QT interval in patients EG1

\begin{tabular}{|l|l|l|l|l|l|}
\hline Indicator & RR triangle & HF & LF & VLF & LF/HF \\
\hline max QT & $0.28 \#$ & $0.35 \#$ & $0.55 \#$ & $0.61 \#$ & $0.31 \#$ \\
& $\mathrm{t}=1.1$ & $\mathrm{t}=1.5$ & $\mathrm{t}=0.1$ & $\mathrm{t}=0.1$ & $\mathrm{t}=1.0$ \\
\hline max QTc & $0.44^{*}$ & $0.22^{* *}$ & $0.32 \#$ & $0.38 \#$ & $0.40^{*}$ \\
& $\mathrm{t}=2.5$ & $\mathrm{t}=4.6$ & $\mathrm{t}=1.1$ & $\mathrm{t}=0.3$ & $\mathrm{t}=2.2$ \\
\hline avg QT & $0.40 \#$ & $0.33 \#$ & $0.42 \#$ & $0.67 \#$ & $0.39 \#$ \\
& $\mathrm{t}=0.3$ & $\mathrm{t}=0.3$ & $\mathrm{t}=0.5$ & $\mathrm{t}=0.1$ & $\mathrm{t}=1.8$ \\
\hline avg QTc & $0.23^{*}$ & $0.18^{* *}$ & $0.19 \#$ & $0.26 \#$ & $0.23^{*}$ \\
& $\mathrm{t}=2.2$ & $\mathrm{t}=3.5$ & $\mathrm{t}=0.1$ & $\mathrm{t}=0.1$ & $\mathrm{t}=2.1$ \\
\hline
\end{tabular}

Note: $*-\mathrm{p}<0.05 ; * *-\mathrm{p}<0.01 ; \#-\mathrm{p}>0.05$ 
In EG1, for the maximum and mean QT values, no significant correlation was found with any of the HRV spectral indicators. For maximal corrected QT, a significant positive mean force correlation was found for RR triangle and LF / HF ( $\mathrm{p}<0.05$ ), also positive and reliable, but of low strength it was for HF. Medium-corrected QT was in weak direct relationship to RR triangle, RR triangle and HF, LF / HF.

Table 22

Relationship HRV spectral characteristics with the duration of QT interval in patients EG2

\begin{tabular}{|l|c|c|c|c|c|}
\hline Indicator & RR triangle & HF & LF & VLF & LF/HF \\
\hline max QT & $0.33 \#$ & $0.29^{*}$ & $0.45 \#$ & $0.48 \#$ & $0.19^{*}$ \\
& $\mathrm{t}=1.5$ & $\mathrm{t}=2.7$ & $\mathrm{t}=1.2$ & $\mathrm{t}=1.6$ & $\mathrm{t}=2.4$ \\
\hline \multirow{2}{*}{$\max$ QTc } & $0.23^{*}$ & $0.28^{*}$ & $0.42 \#$ & $0.40 \#$ & $0.18^{*}$ \\
& $\mathrm{t}=2.1$ & $\mathrm{t}=2.5$ & $\mathrm{t}=1.7$ & $\mathrm{t}=1.8$ & $\mathrm{t}=2.6$ \\
\hline avg QT & $0.22 \#$ & $0.19^{*}$ & $0.44^{*}$ & $0.31 \#$ & $0.47^{*}$ \\
& $\mathrm{t}=1.3$ & $\mathrm{t}=2.2$ & $\mathrm{t}=2.4$ & $\mathrm{t}=1.2$ & $\mathrm{t}=2.5$ \\
\hline avg QTc & $0.21^{*}$ & $0.27^{*}$ & $0.38 \#$ & $0.36 \#$ & $0.22^{*}$ \\
& $\mathrm{t}=2.1$ & $\mathrm{t}=2.5$ & $\mathrm{t}=0.4$ & $\mathrm{t}=1.7$ & $\mathrm{t}=2.7$ \\
\hline
\end{tabular}

Note: $*-p<0.05 ; * *-p<0.01 ; \#-p>0.05$

During the calculation of the correlation coefficient in EG2, a positive weak coupling between maximum QT and HF, LF / HF ( $\mathrm{p}<0.05)$ was revealed; for maximally corrected QT, a significantly positive weak relationship force with RR triangle, HF and LF / HF ( $p<0.05)$. The mean QT value correlates significantly with HF (positive weak correlation), LF (positive mean relationship strength) LF / HF (positive weak correlation). The mean QT correlated significantly with RR triangle, HF and LF / HF $(\mathrm{p}<0.05)$, but this relationship is weak.

Table 23

Relationship HRV spectral characteristics with the duration of QT interval in patients EG3

\begin{tabular}{|l|l|l|l|l|l|}
\hline Indicator & RR triangle & \multicolumn{1}{|c|}{ HF } & \multicolumn{1}{|c|}{ LF } & \multicolumn{1}{|c|}{ VLF } & LF/HF \\
\hline max QT & $0.23 \#$ & $0.35 \#$ & $0.35 \#$ & $0.21 \#$ & $0.48 \#$ \\
& $\mathrm{t}=1.8$ & $\mathrm{t}=0.9$ & $\mathrm{t}=1.3$ & $\mathrm{t}=0.01$ & $\mathrm{t}=0.9$ \\
\hline max QTc & $0.36 \#$ & $0.36^{* *}$ & $0.38^{*}$ & $0.22 \#$ & $0.33^{*}$ \\
& $\mathrm{t}=1.1$ & $\mathrm{t}=3.1$ & $\mathrm{t}=2.2$ & $\mathrm{t}=0.8$ & $\mathrm{t}=2.5$ \\
\hline avg QT & $0.32 \#$ & $0.30^{*}$ & $0.31 \#$ & $0.24^{*}$ & $0.21 \#$ \\
& $\mathrm{t}=4.2$ & $\mathrm{t}=2.1$ & $\mathrm{t}=1.9$ & $\mathrm{t}=2.3$ & $\mathrm{t}=1.6$ \\
\hline avg QTc & $0.28 \#$ & $0.32^{*}$ & $0.25^{*}$ & $0.27^{*}$ & $0.33^{*}$ \\
& $\mathrm{t}=1.8$ & $\mathrm{t}=2.5$ & $\mathrm{t}=2.2$ & $\mathrm{t}=2.9$ & $\mathrm{t}=2.3$ \\
\hline
\end{tabular}

Note: $*-p<0.05 ; * *-p<0.01 ; \#-p>0.05$ 
In EG3 no significant correlation was found between maximum QT and all HRV spectral indices. For the most corrected QT, a significantly positive mean relationship strength with LF, HF, LF / HF was observed. The relationship with HF and VLF was positively positive for the QT mean, the correlation of the mean strength for HF was weak, and weak for VLF. A correlation between mean QT and all HRV spectra except RR triangle $(\mathrm{r}<0.3 ; \mathrm{p}>0.05)$ was significant.

\section{CONCLUSIONS}

1. In patients with ACS a significant increase in supraventricular and ventricular disorders of the heart rhythm was revealed.

2. The analysis of frequency and spectral indicators of heart rate variability during 24-hour Holter ECG monitoring indicates a violation of automatic homeostasis with a general decrease in HRV and with predominance of the parasympathetic nervous system over the sympathetic one, significantly expressed in patients with STsegment elevation.

3.A significant correlation was found between the duration of the maximalcorrected QT and HF intervals which can be applied as an early diagnostic criterion in patients with ACS with or without ST segment elevation.

\section{SUMMARY}

In ischemic myocardium, repolarization processes are disturbed and the risk of arrhythmias, including fatal ones, increases. Acute coronary syndrome (ACS) is one of the manifestations of coronary heart disease (CHD), which is diagnosed in the first hours and days. While recording a normal electrocardiogram (ECG), it is not always possible to record existing abnormalities, so the Holter 24-hour ECG record can be of great significance, in addition it allows to assess the state of the autonomic nervous system (ANS) due to the recording of 24-hour heart rate variability (HRV).

The total number of heartbeats, as well as the heart rate, including the minimum and maximum average minute is not significantly different for the experimental and control groups.

Both supraventricular and ventricular rhythm disturbances have been significantly increased in all study groups as compared to the control one.

All QT indicators for the three study groups have not turned out to bereliable as compared to the control group.

The major frequency and spectral indices of HRV have increased significantlyin patients with ACS.

There is a positive correlation between the increase in the number of supraventricular and ventricular rhythm disorders in patients with ACS.

A significant positive relationship is characteristic of maximal corrected QT and HF in patients with ST elevation. 


\section{REFERENCES}

1. Анікєєва Т.В., Воробйов А.С. Інструментальні та лабораторні можливості оцінки структурно-функціонального стану міокарда у пацієнтів з постінфарктним кардіосклерозом. Кровообіг та гемостаз. 2013. № 2. C. 32-36.

2. Голдовський Б.М., Юрчак Ю.В., Сідь Є.В. Предикторна цінність аналізу варіабельності серцевого ритму в діагностиці фатальних аритмій у хворих із гострим інфарктом міокарда. Медицина неотложных состояний. 2014. № 3(58). С. 109-113.

3. Жарінов О.Й., Сороківський М.С., Черняга-Ройко У.П. Холтерівське моніторування електрокардіограми: еволюція клінічного застосування, діагностичні можливості, показання. Укр. кардіол. журнал. 2004. № 1. С. 122-131.

4. Індика С., Ягенський А., Духневич Л. Варіабельність серцевого ритму у хворих після інфаркту міокарда на амбулаторному етапі реабілітації. Молода спортивна наука Украӥни. 2011. № 3. C. $136-142$.

5. Пархоменко О.М., Кожухов С.М., Іркін О.І., Лутай Я.М. Гостра лівошлуночкова недостатність у хворих на гострий інфаркт міокарда: взаємозв'язок клінічного перебігу та прогнозу з тривалістю синдрому. Раи. фармакотерапия. 2009. № 3(12). С. 51-54.

6. Пархоменко О.М., Гур'єва О.С., Кожухов С.М., Лутай Я.М., Іркін О.І. Перебіг захворювання у хворих із гострим коронарним синдромом із елевацією сегмента ST та збереженою фракцією викиду лівого шлуночка Укр. мед. часопис. 2012. № 3(89). C. $118-123$.

7. Світлик Г.В. Аритмії у пацієнтів 3 гострим інфарктом міокарда $з$ елевацією сегмента ST. Ліки України. 2012. № 9(165). C. $40-43$.

8. Соколов М.Ю., Талаєва Т.В., Ліщишина О.М., Амосова К.М, Божко Л.І., Смець І.М. та ін. Гострий коронарний синдром без елевації сегмента ST адаптована клінічна настанова, заснована на доказах. 2016. C. 101 .

9. Achar S.A., Kundu S., Norcross W.A. Diagnosis of acute coronary syndrome. American Family Physician. 2005. № 72(1). C. $119-126$.

10. Fox K. A., Eagle K., Gore J. M., Steg P. G., Anderson F. A. The Global Registry of Acute Coronary Events, 1999 to 2009-GRACE. Heart 2010. № 96. C. 1095-1101. doi: 10.1136/hrt.2009.190827. 
11.Zipes D. P., Camm A. J., Borggefe M., Buxton A. E., Chaitman B., Fromer M. et al. Guidelines for the Management of Patients With Ventricular Arrhythmias and the Prevention of Sudden Cardiac Death: Executive Summery. Circulation. 2006. № 114. C. 1088-1132. URL: https://doi.org/10.1016/j.jacc.2006.07.010.

\section{Information about author:} Bilous Z. O., Candidate of Medical Sciences, Associate Professor at the Department of Internal Medicine Lviv National Medical University 15/12, Osvytska str., Lviv, Ukraine 